\title{
A Rare Coexistence of Birt-Hogg-Dubé Syndrome and Sarcoidosis
}

\author{
Birt-Hogg-Dubé Sendromu ve Sarkoidozun Nadir Birlikteliği \\ Celal Sałıcı', Gizem Köybaşı', Ayșe Koyukan², Ekrem Cengiz Seyhan'
}

\begin{abstract}
A pathophysiological link may exist between BirtHogg-Dubé syndrome (BHD) and pulmonary sarcoidosis such that the folliculin protein encoded by the FLCN gene may lead to the development of sarcoidosis through the upregulation of T- helper 1 cell activation. We present here a rare case of coexisting BHD and sarcoidosis. Enlarged mediastinal lymphadenopathy may be underdiagnosed in patients with $\mathrm{BHD}$, and so both the mediastinal and lung window of a thoracic CT scan should be evaluated carefully and a biopsy should be performed if pathologic lymphadenopathies are indicated.
\end{abstract}

Key words: Birt Hogg Dubé, sarcoidosis, fibrofolliculoma, mediastinal lymphadenopathy.

\section{Özet}

Birt-Hogg-Dube (BHD) sendromuna sahip hastalarda FLCN geni tarafindan kodlanan folliculin proteininin T-helper-1 hücre aktivasyonuna yol açarak sarkoidoza yol açabileceği ve bu sebeple bu iki hastalık arasında patofizyolojik bir ortaklık olabileceği düşünülmektedir. Burada nadir bir BHD sendromu ve sarkoidoz birlikteliği olgusunu sunuyoruz. BHD tanısı alan hastaların toraks bilgisayarlı tomografilerinin hem parankim hem de mediasten penceresinde olası bir mediastinal lenfadenopatiyi gözden kaçırmamak adına detaylı olarak incelenemeli ve patolojik boyutta bir lenf nodu mevcut ise biyopsi yapılmalıdır.

Anahtar Sözcükler: Birt Hogg Dubé, sarkoidoz, fibrofolikulom, mediastinal lenfadenopati.
'Department of Chest Disesases, University of Health Sciences, Yedikule Research and Training Hospital for Chest Diseases and Chest Surgery, İstanbul, Turkey

${ }^{2}$ Department of Pathology, University of Health Sciences, Yedikule Research and Training Hospital for Chest Diseases and Chest Surgery, Istanbul, Turkey
'Sağlık Bilimleri Üniversitesi, Yedikule Göğüs Hastalıkları Ve Göğüs Cerrahisi Eğitim Ve Araşıırma Hastanesi, Göğüs Hastalıkları anabilim Dalı, İstanbul

${ }^{2}$ Sağlık Bilimleri Üniversitesi, Yedikule Göğüs Hastalıkları Ve Göğüs Cerrahisi Eğitim Ve Araşıırma Hastanesi, Patoloji Anabilim Dalı, İstanbul

Submitted (Başvuru tarihi): 18.02.2021 Accepted (Kabul tarihi): 16.04.2021

Correspondence (iletişim): Celal Satıcı, Department of Chest Disesases, University of Health Sciences, Yedikule Research and Training Hospital for Chest Diseases and Chest Surgery, İstanbul, Turkey

e-mail: celalsatici@yahoo.com 
Birt-Hogg-Dubé (BHD) syndrome is a rare autosomal dominant disorder caused by an FLCN gene mutation, and is characterized by lung cysts, and benign skin and renal tumors $(1,2)$. Sarcoidosis is a granulomatous disease that mostly occurs with mediastinal lymphadenopathies and lung parenchymal abnormalities. The coexistence of BHD and sarcoidosis is extremely rare, having been reported only once before, and it is still unknown whether such co-existences are coincidental, or whether a causal link between the two exists. One possible pathophysiological link is that folliculin, a product of the FLCN gene, has an effect on the upregulation of T-helper 1 cells, and leading to the granulomatous reaction seen in sarcoidosis (3). We contribute to literature here with a second case of co-existing BHD and sarcoidosis.

\section{CASE}

A 26-year-old male patient was admitted to our hospital with a complaint of intermittent chest pain for 10 years, and was diagnosed with Birt-Hogg-Dubé (BHD) syndrome after a punch biopsy revealed fibrofolliculo$\mathrm{ma}$ /trichodiscoma in the skin-colored lesions on his face. The patient was genetically tested for BHD, and a positive heterozygote folliculin (FLCN) gene mutation (c.1285dupC) was identified. During follow-up visits, family screening for familial association produced positive results in his brother and mother. The patient was otherwise healthy and had no history of smoking. Systemic physical examination findings were unremarkable aside from multiple, skin-colored, smooth and dome-shaped papules ranging in size from $1-4 \mathrm{~mm}$ in diameter, covering most of his face (Figure 1). Vital signs were normal. In laboratory tests, complete blood count, electrolytes and renal function were normal, while his angiotensinconverting enzyme (ACE) level was elevated, at 54 units per liter. A chest X-ray revealed bilateral enlarged hilar shadows with no pulmonary infiltrates (Figure 2). A thorax computed tomography (CT) was performed in which multiple mediastinal lymph nodes were identified, the largest being $13 \mathrm{~mm}$ in diameter, in the aortopulmonary window, subcarinal, right lower paratracheal and bilateral hilar regions, but with no parenchymal abnormality (Figure 3). An Endobronchial Ultrasonography (EBUS) identified four round, homogeneous and fused lymph nodes with regular borders in the right lower paratracheal area measuring 10-15 mm in diameter, and a round and homogeneously enlarged lymph node with a maximum diameter of $10 \mathrm{~mm}$ in the subcarinal station was sampled. A histopathological examination revealed non-necrotizing chronic granulomatous lymphadenitis, and the patient was diagnosed with stage 1 Sarcoidosis (Figure 4). The histochemical staining panel results for Grocott-Gomori's methenamine silver (GMS), Periodic acid-Schiff (PAS) and Acid-Fast stain (AFB) were negative, the result of a purified protein derivative (PPD) test was $0 \mathrm{~mm}$, and abdominal ultrasound revealed no abnormality. Since the patient had only stage 1 Sarcoidosis and no other organ involvement, only follow-up was planned for the detection of any renal lesions that may develop. Considering all these findings, the patient was diagnosed with coexisting Birt-Hogg-Dubé syndrome and sarcoidosis.

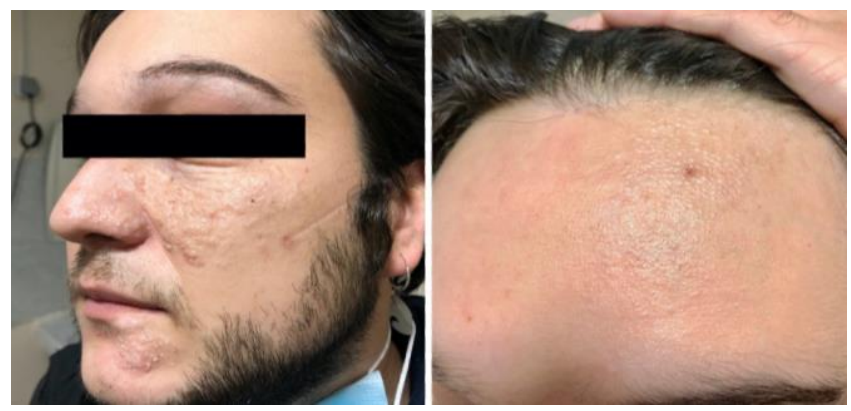

Figure 1: Multiple skin-colored, dome-shaped papules measuring 1-3 $\mathrm{mm}$ in diameter; fibrofolliculomas covering the patient's face

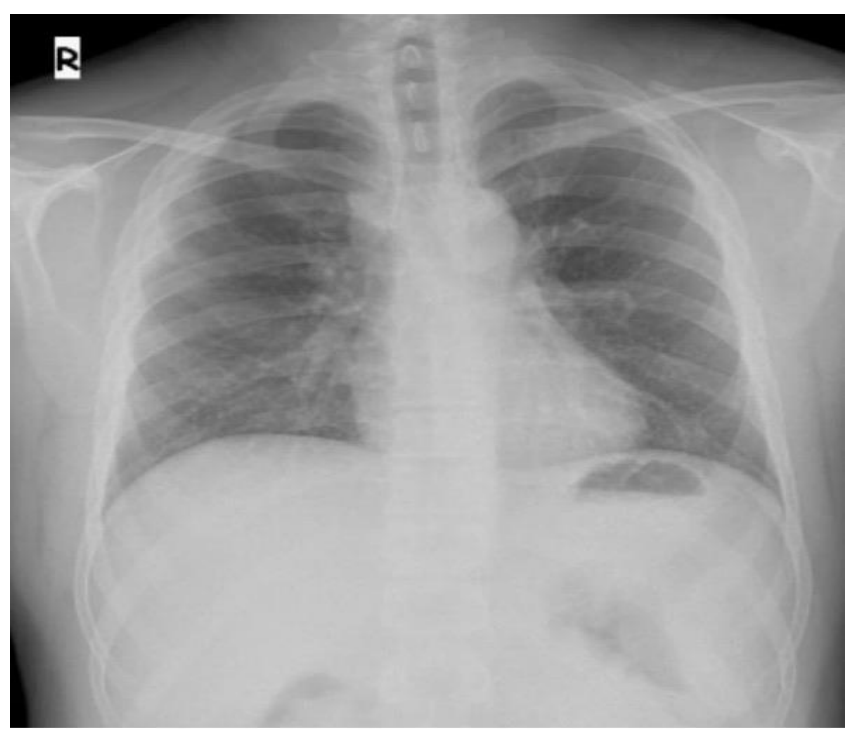

Figure 2: Chest $X$-ray

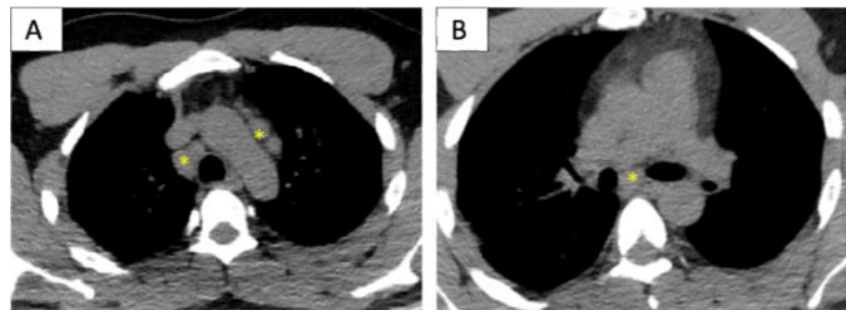

Figure 3: Axial unenhanced chest CT images showing enlarged mediastinal lymph nodes: CT image showing enlarged lymph nodes in the aortopulmonary window and the right lower paratracheal region (a), CT image showing an enlarged lymph node in the subcarinal region (b) 


\section{DISCUSSION}

Birt-Hogg-Dubé syndrome was first described in 1977 as a case series including 70 kindred patients with skin manifestations, including cutaneous fibrofolliculoma / trichodiscoma. BHD is a rare inherited autosomal dominant disorder that has been reported in around 200 families (1), and is caused by germline mutations in the tumor suppressor gene FLCN. Besides skin manifestations, multiple pulmonary cysts with or without pneumothorax and renal tumors of various histological types are other organ involvements (2). There is no difference in frequency in terms of gender (4). More than $80 \%$ of patients with BHD have multiple pulmonary cysts with irregular borders, and patients often present with pneumothorax in the subpleural regions, predominantly in the lower lobes (3), although some BHD patients may be diagnosed with BHD without pulmonary cysts, as in the present case. A BHD diagnosis is based on clinical features and/or the identification of the genetic germ line FLCN mutation. Menko et al. (1) defined the major diagnostic criteria (a. at least five fibrofolliculomas/trichodiscomas, at least one being histologically confirmed adult onset b. pathogenic FLCN germline mutation) and the minor diagnostic criteria (a. multiple lung cysts b. renal tumor $c$. a first-degree relative with BHD). Of these, one major or two minor criteria are needed for diagnosis. Our case, whose family members were positive for FLCN gene mutation, was diagnosed with BHD after meeting two major criteria.

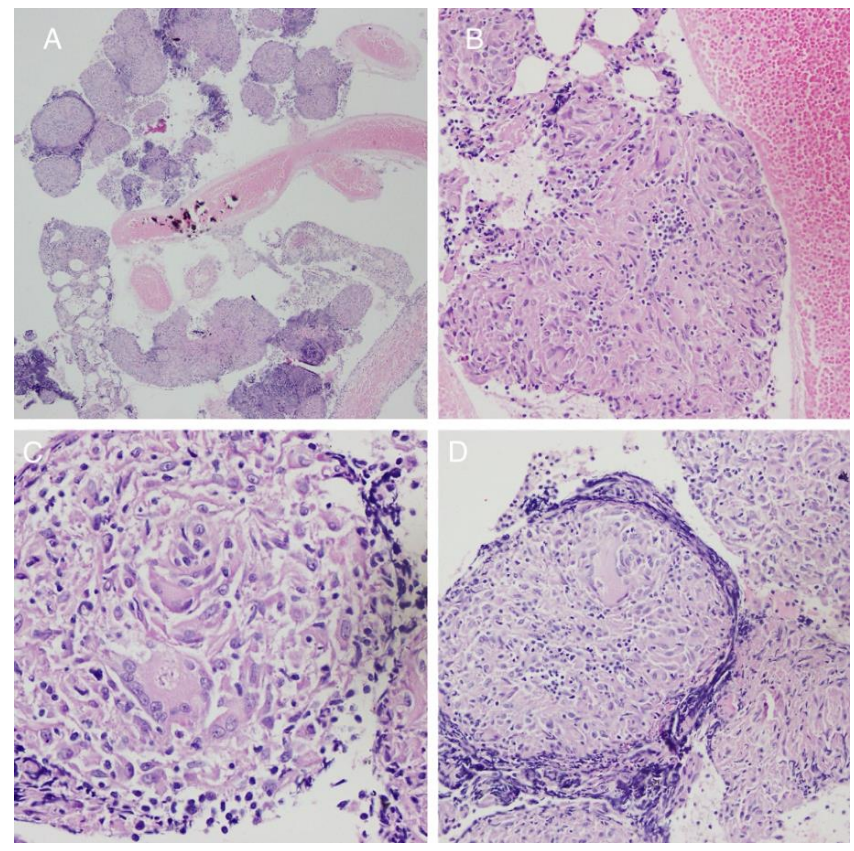

Figure 4: Non-necrotizing granuloma formation, including aggregates of epithelioid histiocytes (a-b) and multinucleated giant cell, whose cytoplasm includes an asteroid body (c-d)
Enlarged mediastinal lymphadenopathy is an atypical finding in patients with BHD, and the probability of concurrently having BHD and sarcoidosis is assumed to be 1 in 9.5 billion. In literature, the only reported case diagnosed with both BHD and sarcoidosis involved a 57 -yearold male patient with bulky hilar lymphadenopathy and peribronchiolar consolidations, identified with multiple pulmonary cysts from thoracic CT (4). The authors hypothesized that a possible pathophysiological link may exist between the diseases in which folliculin, a protein produced by the FLCN gene, has an effect on the mammalian target of rapamycin (mTOR) pathway, and the upregulation of T-helper $1(\mathrm{TH} 1)$ cells promoted AKTmTOR enhancement in this case, leading to the concurrence of BHD and sarcoidosis. In a further study, Kumasaka et al. (5) analyzed histopathological findings from the lung parenchyma obtained during video-assisted thoracic surgery in 50 unrelated patients with BHD. Among these, a granuloma formation and a c. 1285dupC FLCN gene mutation were detected together in two patients, similar to our case, while patients without granuloma formations had other FLCN gene mutations.

The coexistence of BHD and sarcoidosis has been reported to be extremely rare, although this may be due to the underdiagnosis of enlarged mediastinal lymphadenopathies. It remains unclear as to whether the coexistence is causal or incidental, and so accompanying histopathological findings should be reported to reveal whether any causal relationship. As granulomatous diseases such as sarcoidosis may accompany BHD disease, both the mediastinal and lung window of thorax CT scan should be evaluated, and a biopsy should be performed during follow-up if indicated.

\section{CONFLICTS OF INTEREST}

None declared.

\section{AUTHOR CONTRIBUTIONS}

Concept - C.S., G.K., A.K., E.C.S.; Planning and Design - C.S., G.K., A.K., E.C.S.; Supervision - C.S., G.K., A.K., E.C.S.; Funding - C.S., G.K.; Materials - C.S., G.K., A.K.; Data Collection and/or Processing - C.S., G.K.; Analysis and/or Interpretation - C.S., E.C.S.; Literature Review C.S.; Writing - C.S.; Critical Review - C.S., G.K., A.K., E.C.S. 


\section{YAZAR KATKILARI}

Fikir - C.S., G.K., A.K., E.C.S.; Tasarım ve Dizayn - C.S., G.K., A.K., E.C.S.; Denetleme - C.S., G.K., A.K., E.C.S.; Kaynaklar - C.S., G.K.; Malzemeler - C.S., G.K., A.K.; Veri Toplama ve/veya İşleme - C.S., G.K.; Analiz ve/veya Yorum - C.S., E.C.S.; Literatür Taraması - C.S.; Yazıyı Yazan - C.S.; Eleştirel İnceleme - C.S., G.K., A.K., E.C.S.

\section{REFERENCES}

1. Menko FH, van Steensel MA, Giraud S, Friis-Hansen L, Richard S, Ungari S, et al. European BHD Consortium. Birt-Hogg-Dubé syndrome: diagnosis and management. Lancet Oncol 2009; 10:1199-206. [CrossRef]
2. Daccord C, Good JM, Morren MA, Bonny O, Hohl D, Lazor R. Birt-Hogg-Dubé syndrome. Eur Respir Rev 2020; 29:200042. [CrossRef]

3. Kuhn B, Teckchandani P, Harper R. Parsimony or poor luck: Concurrent Birt-Hogg- Dubé syndrome and sarcoidosis. Sarcoidosis Vasc Diffuse Lung Dis 2017; 34:194-6. [CrossRef]

4. Gupta N, Sunwoo BY, Kotloff RM. Birt-Hogg-Dubé syndrome. Clin Chest Med 2016; 37:475-86. [CrossRef]

5. Kumasaka T, Hayashi T, Mitani K, Kataoka H, Kikkawa $M$, Tobino $K$, et al. Characterization of pulmonary cysts in Birt-Hogg-Dubé syndrome: histopathological and morphometric analysis of 229 pulmonary cysts from 50 unrelated patients. Histopathology 2014; 65:100-10. [CrossRef] 